MaPan : Jurnal Matematika dan Pembelajaran

p-ISSN: 2354-6883 ; e-ISSN: 2581-172X

Volume 5, Nomor 1, Juni 2017

\title{
KEMAMPUAN METAKOGNISI UNTUK MENINGKATKAN KETERAMPILAN PEMECAHAN MASALAH MATEMATIKA SISWA KELAS VIII B MTS MADANI ALAUDDIN PAOPAO KABUPATEN GOWA
}

\author{
Thamrin Thayeb ${ }^{1)}$, Anita Purnama Putri ${ }^{2)}$ \\ 1,2Fakultas Tarbiyah dan Keguruan UIN Alauddin Makassar \\ 1,2Kampus II: Jalan H. M. Yasin Limpo Nomor 36 Samata-Gowa \\ E-mail: thamrinthayeb@yahoo.com ${ }^{1)}$, anitapurnama.putri@yahoo.com ${ }^{2)}$
}

\begin{abstract}
Abstrak
Penelitian ini bertujuan untuk mengetahui apakah kemampuan metakognisi dapat meningkatkan keterampilan pemecahan masalah matematika siswa kelas VIII B MTs. Madani Alauddin PaoPao Kabupaten Gowa. Pada proses penerapan model pembelajaran metakognitif berbasis masalah terbuka, siswa terlatih menggunakan kemampuan metakognisinya mulai dari awal pemecahan masalah matematika hingga pada bagian akhir berupa rumusan jawaban serta melakukan evaluasi untuk memastikan pencapaian tujuan berkaitan dengan pemecahan masalah matematika yang diberikan. Penerapan model pembelajaran metakognitif berbasis masalah terbuka dapat meningkatkan keterampilan pemecahan masalah matematika siswa. Peningkatan ini terlihat setelah penerapan model pembelajaran yang lebih menekankan pada aktivitas siswa dalam mengerahkan kesadaran dan pengaturan berpikirnya (metakognisi). Selain itu, dari empat indikator pemecahan masalah yang diukur, semuanya mengalami peningkatan dari siklus I ke siklus II. Secara umum, penerapan model pembelajaran metakognitif ini, menyebabkan skor kemampuan memecahkan masalah matematika siswa mengalami peningkatan dari sebelumnya. Adanya peningkatan ini dikarenakan oleh penerapan model pembelajaran yang lebih menekankan pada keaktifan siswa dalam kegiatan pembelajaran, sedangkan guru hanya berperan sebagai fasilitator.
\end{abstract}

Kata Kunci: Kemampuan Metakognisi, Pemecahan Masalah Matematika

$\mathrm{P}$ endidikan pada dasarnya adalah usaha sadar untuk menumbuhkembangkan potensi sumber daya manusia peserta didik dengan cara mendorong dan memfasilitasi kegiatan belajar mereka. Undang-Undang RI Nomor 20 Tahun 2003 tentang Sistem Pendidikan Nasional Bab 1 Pasal 1 (1) pendidikan didefinisikan sebagai usaha sadar dan terencana untuk mewujudkan suasana belajar dan proses belajar agar peserta didik secara aktif mengembangkan potensi dirinya, masyarakat, bangsa dan 
negara. Dalam hal ini, tentu saja diperlukan adanya pendidik yang profesional terutama guru di sekolah-sekolah dasar dan menengah dan dosen di perguruan tinggi (Muhibbin Syah, 2006: 1).

National Council of Teachers of Mathematics atau NCTM (2000), menyatakan bahwa standar matematika sekolah haruslah meliputi standar isi dan standar proses. Standar proses meliputi pemecahan masalah, penalaran dan pembuktian, keterkaitan, komunikasi, dan representasi. Pentingnya pemilikan kemampuan pemecahan masalah oleh siswa dalam matematika dikemukakan oleh Branca (1980) sebagai berikut: (1) kemampuan pemecahan masalah merupakan tujuan umum pengajaran matematika, bahkan sebagai jantungnya matematika; (2) pemecahan masalah meliputi metode, prosedur, dan strategi merupakan proses inti dan utama dalam kurikulum matematika; dan (3) pemecahan masalah merupakan kemampuan dasar dalam belajar matematika. Sebagai implikasi dari pendapat di atas, maka kemampuan pemecahan masalah hendaknya dimiliki oleh semua anak yang belajar matematika mulai dari tingkat Sekolah Dasar sampai Perguruan Tinggi.

Kenyataan yang terjadi di MTs. Madani Pao-Pao yakni siswa mampu mengerjakan soal yang sejenis dengan soal yang sudah diterangkan guru. Namun, mereka sangat lemah dalam menyelesaikan soal-soal nonrutin yang berkaitan dengan pemecahan masalah yang memerlukan penalaran matematis. Hal ini berdampak pada rendahnya hasil belajar matematika siswa. Selain itu, siswa mengibaratkan matematika sebagai momok yang menakutkan, tidak menarik dan membosankan karena menurutnya matematika termasuk pelajaran yang sulit.

Salah satu penyebab dianggap sulitnya matematika oleh siswa adalah pembelajaran matematika yang sarat akan konsep-konsep matematis tanpa disertai implementasinya dalam kehidupan sehari-hari. Hal ini mengakibatkan matematika dipandang sebagai suatu ilmu yang abstrak dan sulit diterapkan dalam kehidupan nyata sehingga mayoritas siswa tidak tertarik dengan matematika. Namun, karena kemampuan menyelesaikan masalah merupakan tujuan umum pengajaran matematika, maka siswa haruslah belajar matematika agar dapat membantu dirinya dalam memecahkan persoalan baik dalam pelajaran lain maupun dalam kehidupan sehari-hari.

Proses menyadari kemampuan dan mengatur berpikir siswa dalam memecahkan masalah dikenal sebagai metakognisi. Metakognisi pada hakikatnya memberikan penekanan pada kesadaran berpikir seseorang 
tentang proses berpikirnya sendiri. O’Neil \& Brown (1997) menyatakan bahwa metakognisi sebagai proses seseorang berpikir dalam rangka membangun strategi untuk memecahkan masalah. Konsep dari metakognisi adalah ide dari berpikir tentang pikiran pada diri sendiri. Termasuk kesadaran tentang apa yang diketahui seseorang (pengetahuan metakognitif), apa yang dapat dilakukan seseorang (keterampilan metakognitif) dan apa yang diketahui seseorang tentang kemampuan kognitif dirinya sendiri (pengalaman metakognitif). Selain itu, penelitian ini juga bertujuan untuk mengetahui apakah kemampuan metakognisi dapat meningkatkan keterampilan pemecahan masalah matematika siswa kelas VIII B MTs. Madani Alauddin PaoPao Kabupaten Gowa.

\section{METAKOGNISI}

Pentingnya metakognisi diperkenalkan ke dunia pendidikan pada 1976 oleh Flavell. Wellman (1985) menyatakan bahwa metakognisi sebagai suatu bentuk kognisi, atau proses berpikir dua tingkat atau lebih yang melibatkan pengendalian terhadap aktivitas kognitif. Flavell mendefinisikan metakognisi, Metacognition as the ability to understand and monitor one's own thoughts and the assumptions and implications of one's activities. Metakognisi sebagai kemampuan untuk memahami dan memantau berpikir diri sendiri dan asumsi serta implikasi kegiatan seseorang. Pendapat ini menekankan metakognisi sebagai kemampuan untuk memahami dan memantau kegiatan berpikir, sehingga proses metakognisi tiap-tiap orang akan berbeda menurut kemampuan (Anggo, 2011: 26).

Flavel (Livingston, 1997) mengemukakan bahwa metakognisi meliputi dua komponen, yaitu: (1) pengetahuan metakognitif (metacognitive knowledge). Pengetahuan metakognitif terdiri dari sub kemampuan yakni pengetahuan deklaratif (declarative knowledge), pengetahuan prosedural (procedural knowledge), pengetahuan kondisional (conditional knowledge); (2) pengalaman atau regulasi metakongnisi (metacognitive experiences or regulation). Regulasi metakognitif terdiri dari sub-kemampuan sebagai berikut: (a) Planning; (b) Information management strategies; (c) comprehension monitoring; (d) debugging strategies; dan (e) evaluation.

\section{MASALAH MATEMATIKA}

Krulik dan Rudnik (1995: 11) mendefiniskan masalah secara formal sebagai: A problem is a situation, quantitative $\mathrm{pr}$ otherwise, that confront an individual or group of individuals, that requires resolution, and for which the 
individual sees no apparent or obvious or path to obtaining a solution. Definisi tersebut menjelaskan bahwa masalah adalah suatu situasi, yang bersifat kuantitatif atau sebaliknya, yang dihadapi oleh seseorang atau sekelompok orang yang memerlukan suatu pemecahan, akan tetapi seseorang atau sekelompok tersebut tidak memiliki cara langsung untuk menyelesaikannya. Menurut Hudoyono (dalam Alimuddin, 2012: 75) jenis-jenis masalah matematika yakni masalah translasi, masalah aplikasi, masalah proses, dan masalah teka-teki.

\section{PEMECAHAN MASALAH MATEMATIKA}

Solso dan Maclin (2008: 434) mengemukakan bahwa pemecahan masalah adalah suatu pemikiran yang terarah secara langsung untuk menemukan suatu solusi/jalan keluar untuk suatu masalah yang spesifik. Tahapan pemecahan masalah yang dikemukakan oleh Hayes (dalam Solso dan Maclin, 2008: 437), yaitu: mengidentifikasi permasalahan, representasi masalah, merencanakan sebuah solusi masalah, merealisasikan rencana, mengevaluasi rencana, dan mengevaluasi solusi.

Langkah pemecahan masalah matematika yang terkenal dikemukakan oleh G.Polya, dalam bukunya "How to Solve It". Empat langkah pemecahan masalah matematika menurut G. Polya tersebut adalah: "(1) understanding the problem, (2) devising plan, (3) carrying out the plan, (4) looking back".

\section{METODE PENELITIAN}

Jenis penelitian yang digunakan adalah penelitian tindakan kelas (Classroom Action Research). Penelitian tindakan kelas adalah penelitian yang dilakukan oleh guru di kelasnya sendiri dengan cara: (1) merencanakan, (2) melaksanakan, dan (3) merefleksikan tindakan secara kolaboratif dan partisipatif dengan tujuan memperbaiki kinerjanya sebagai guru, sehingga hasil belajar siswa dapat meningkat. Penelitian dilaksanakan di MTs. Madani Pao-Pao Kabupaten Gowa. Model yang digunakan dalam penelitian ini adalah model penelitian tindakan kelas yang dikemukakan oleh Kemmis dan Mc. Taggart.

Subjek penelitian adalah siswa kelas VIII B MTs Madani Pao-Pao, Kabupaten Gowa. Instrument yang digunakan adalah untuk tes pemecahan masalah matematika berbentuk soal uraian dan lembar observasi yakni lembar observasi siswa dan keterlaksanaan pembelajaran. Teknik analisis data yang 
digunakan adalah statistik deskriptif yaitu analisis data observasi dan analisis data keterampilan pemecahan masalah matematika.

\section{HASIL PENELITIAN DAN PEMBAHASAN}

\section{Deskripsi Tindakan Pra-Siklus}

Tabel 1. Hasil Observasi Siswa pada Proses Pembelajaran Pra-Siklus

\begin{tabular}{clcc}
\hline No. & \multicolumn{1}{c}{ Kegiatan Siswa } & $\begin{array}{c}\text { Rata-rata } \\
\mathbf{( \% )}\end{array}$ & Kategori \\
\hline 1. & Tidak merespon penjelasan guru & 83,86 & Sangat Tinggi \\
2. & Menjawab pertanyaan guru & 6,89 & Sangat Rendah \\
3. & Mengajukan pertanyaan pada guru & 10,53 & Sangat Rendah \\
4. & Mengemukakan pendapat & 23,07 & Rendah \\
5. & Tidak memberikan umpan balik pada & 38,36 & Rendah \\
& guru & 16,38 & Sangat Rendah \\
6. & Merespon pendapat teman & &
\end{tabular}

Tabel 2. Hasil Obeservasi Guru pada Proses Pembelajaran Pra-Siklus

\begin{tabular}{ll}
\hline No. & \multicolumn{1}{c}{ Kegiatan Guru } \\
\hline 1. & Tidak mengaitkan materi sebelumnya dengan materi yang akan \\
& dipelajari \\
2. & Memberikan pertanyaan beberapa kali kepada siswa \\
3. & Tidak menggunakan media penunjang pembelajaran \\
4. & Metode ynag digunakan adalah metode ceramah dan Tanya jawab \\
5. & Kurang mengeksplorasi kemampuan berpikir siswa \\
\hline
\end{tabular}

\section{Deskripsi Tindakan Tiap Tahap Siklus}

a. Tahap Perencanaan

Tabel 3. Perencanaan Tindakan Siklus I dan Siklus II

\begin{tabular}{lllll}
\hline & \multicolumn{2}{c}{ Siklus I } & \multicolumn{1}{c}{ Siklus II } \\
\hline No & Kegiatan & \multicolumn{1}{c}{ Keterangan } & Kegiatan & \multicolumn{1}{c}{ Keterangan } \\
\hline 1. & Identifikasi & Berkolaborasi & Menyusun & Berkolaborasi dengan \\
& Masalah & dengan guru & Perangkat & guru \\
& melakukan & Pembelaja- & mengembangkan \\
& identifikasi masalah ran & perangkat \\
& melalui observasi & pembelajaran \\
& proses pembelajaran & meliputi RPP, LKS, \\
& dan dokumentasi. & media pembelajaran \\
\hline
\end{tabular}




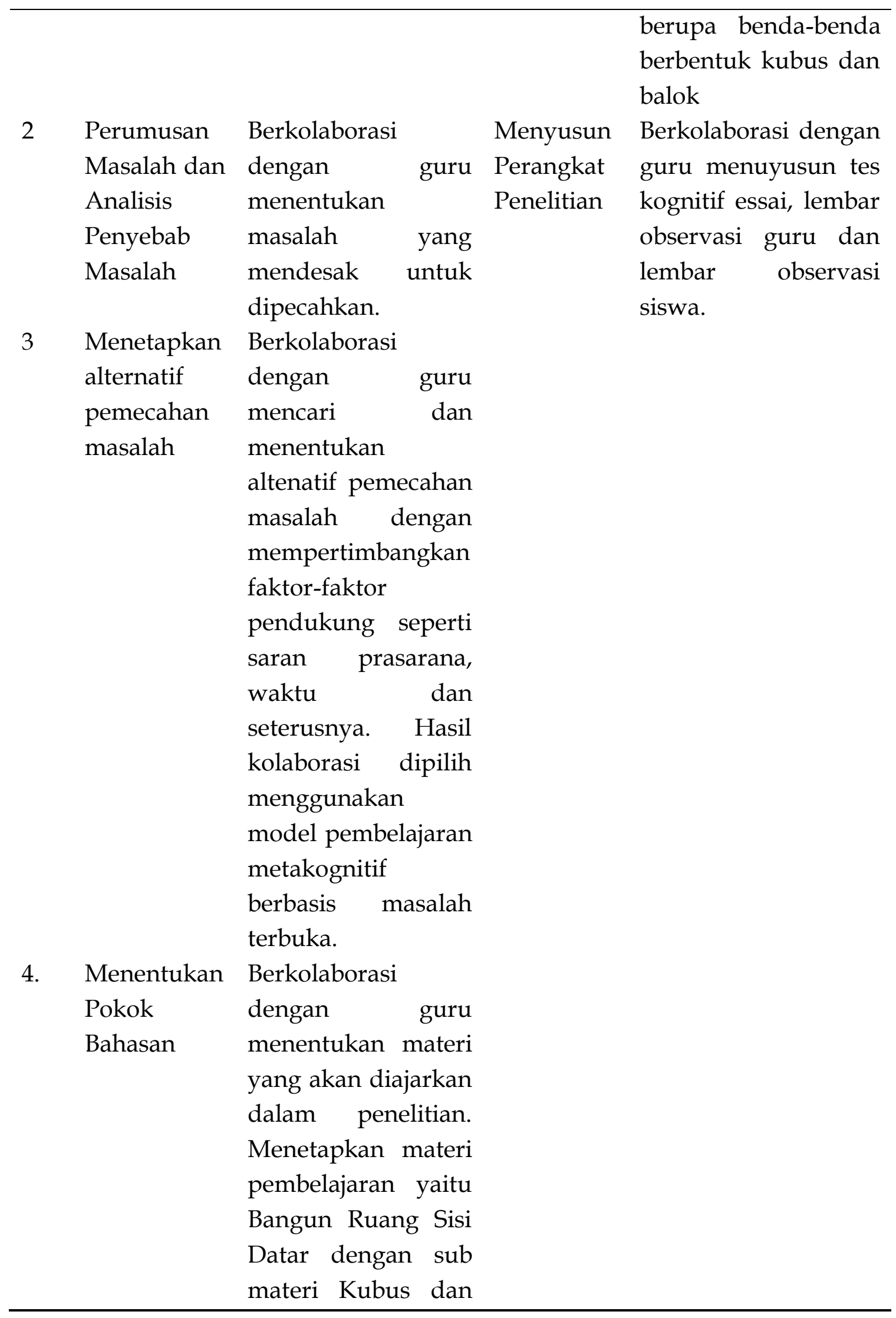

6 | Volume 5, Nomor 1, Juni 2017 


\begin{tabular}{lll}
\hline & Balok. \\
5. & Menyusun & Berkolarasi dengan \\
Perangkat & guru menyusun \\
Pembelaja- & perangkat \\
ran & pembelajaran \\
& meliputi RPP dan \\
& LKS. \\
Menyusun & Menyusun tes \\
Perangkat & kognitif essai, \\
Penelitian & lembar observasi \\
& guru dan lembar \\
& observasi peserta \\
& didik \\
\hline
\end{tabular}

b. Tahap Pelaksanaan

Tabel 4. Pelaksanaan Tindakan Pembelajaran Siklus I

\begin{tabular}{|c|c|c|}
\hline $\begin{array}{c}\text { Tahap } \\
\text { Pembelajaran }\end{array}$ & Aktivitas Guru & Aktivitas Siswa \\
\hline \multicolumn{3}{|l|}{ Kegiatan Awal } \\
\hline \multirow[t]{2}{*}{ a. Pendahuluan } & $\begin{array}{l}\text { Membuka pelajaran dengan } \\
\text { mengucapkan salam dan } \\
\text { mengabsen siswa }\end{array}$ & Menjawab salam guru \\
\hline & $\begin{array}{l}\text { Mengecek kesiapan siswa } \\
\text { untuk belajar }\end{array}$ & $\begin{array}{l}\text { Mempersiapkan buku } \\
\text { pelajaran matematika }\end{array}$ \\
\hline $\begin{array}{l}\text { b. Apersepsi } \\
\text { dan Motivasi }\end{array}$ & $\begin{array}{l}\text { Memotivasi siswa dengan } \\
\text { mengajukan pertanyaan }\end{array}$ & $\begin{array}{l}\text { Menjawab pertanyaan } \\
\text { guru }\end{array}$ \\
\hline \multicolumn{3}{|l|}{ Kegiatan Inti } \\
\hline a. Eksplorasi & $\begin{array}{l}\text { Membagi siswa ke dalam } 5 \\
\text { kelompok }\end{array}$ & $\begin{array}{l}\text { Bergabung } \\
\text { kelompoknya }\end{array}$ \\
\hline \multirow[t]{3}{*}{ - } & $\begin{array}{l}\text { Menjelaskan materi volume } \\
\text { kubus dan balok }\end{array}$ & $\begin{array}{l}\text { Menyimak penjelasan } \\
\text { guru }\end{array}$ \\
\hline & Memberikan contoh soal & $\begin{array}{l}\text { Menyimak contoh yang } \\
\text { diberikan guru }\end{array}$ \\
\hline & $\begin{array}{l}\text { Membagikan LKS pada } \\
\text { masing-masing kelompok. }\end{array}$ & Mengerjakan LKS \\
\hline b. Elaborasi & Memperhatikan, memotivasi, & Berdiskusi \\
\hline
\end{tabular}




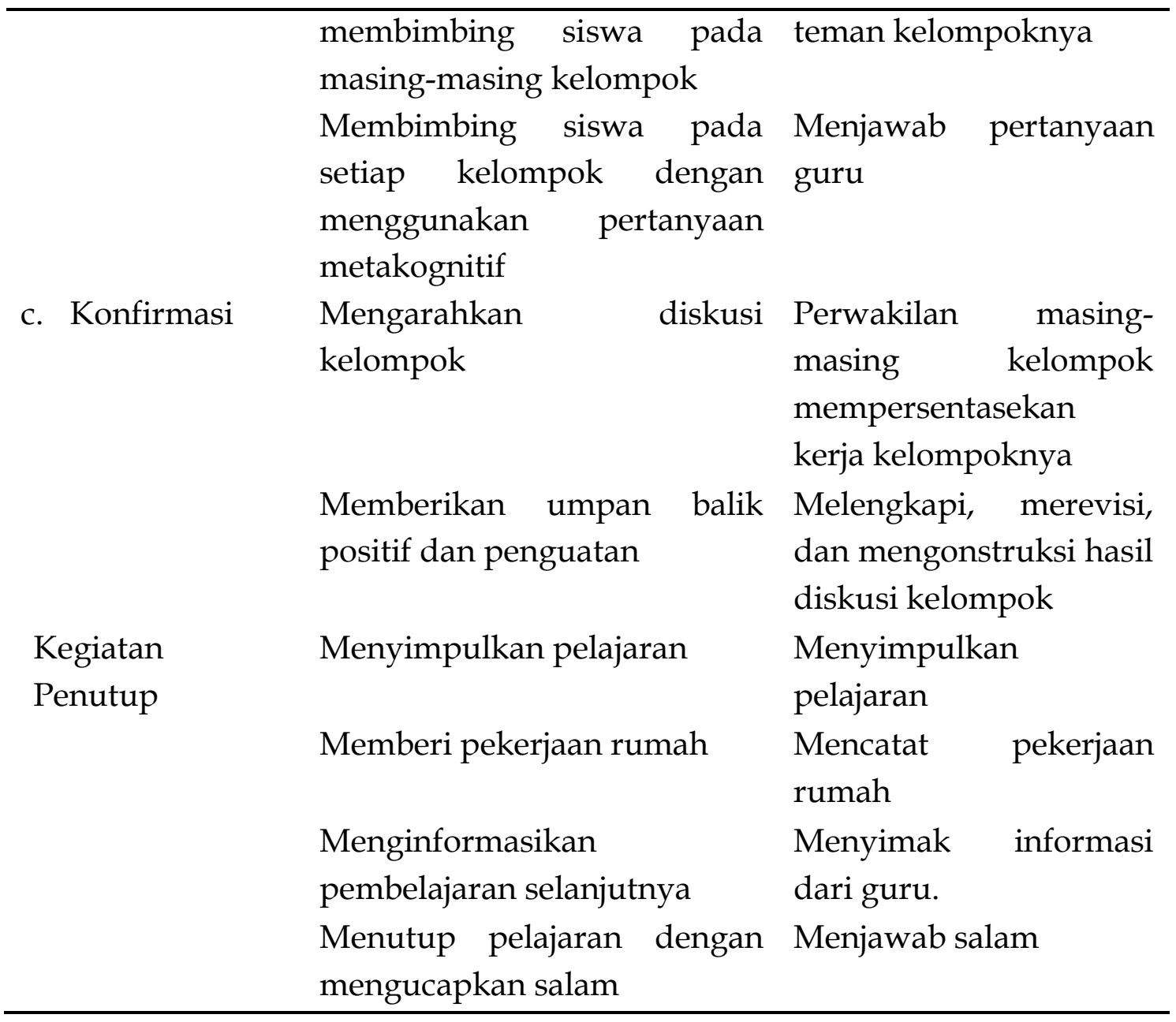

Tabel 5. Pelaksanaan Tindakan Pembelajaran Siklus II

\begin{tabular}{|c|c|c|}
\hline $\begin{array}{c}\text { Tahap } \\
\text { Pembelajaran }\end{array}$ & Aktivitas Guru & Aktivitas Siswa \\
\hline $\begin{array}{l}\text { Kegiatan Awal } \\
\text { a. Pendahuluan }\end{array}$ & $\begin{array}{l}\text { Membuka } \\
\text { dengan melajaran } \\
\text { salam dan mengabsen } \\
\text { siswa }\end{array}$ & $\begin{array}{l}\text { Menjawab salam } \\
\text { memperhatikan guru }\end{array}$ \\
\hline \multirow{3}{*}{$\begin{array}{l}\text { b. Apersepsi } \\
\text { dan Motivasi }\end{array}$} & $\begin{array}{l}\text { Mengecek kesiapan siswa } \\
\text { untuk belajar }\end{array}$ & $\begin{array}{ll}\text { Mempersiapkan } & \text { buku } \\
\text { pelajaran matematika } & \end{array}$ \\
\hline & $\begin{array}{lr}\text { Memotivasi } & \text { siswa } \\
\text { dengan } & \text { mengajukan }\end{array}$ & Menjawab pertanyaan guru \\
\hline & pertanyaan & Mengingat kembali materi \\
\hline
\end{tabular}




\begin{tabular}{|c|c|c|}
\hline & $\begin{array}{l}\text { Meminta } \\
\text { mengingat kembali } \\
\text { pelajaran volume kubus } \\
\text { dan balok } \\
\text { Menunjukkan alat peraga } \\
\text { kubus dan balok dan } \\
\text { meminta siswa } \\
\text { menemukan hubungan } \\
\text { luas persegi dengan luas } \\
\text { permukaan kubus dan } \\
\text { hubungan luas persegi } \\
\text { panjang dengan luas } \\
\text { permukaan balok }\end{array}$ & $\begin{array}{l}\text { Memperhatikan guru dan } \\
\text { Mencari dan } \\
\text { mengemukakan pendapat } \\
\text { tentang keterkaitan antara } \\
\text { luas persegi dengan luas } \\
\text { permukaan kubus dan } \\
\text { hubungan antara luas } \\
\text { persegi panjang dengan } \\
\text { luas permukaan balok }\end{array}$ \\
\hline \multirow[t]{4}{*}{$\begin{array}{l}\text { Kegiatan Inti } \\
\text { a. Eksplorasi }\end{array}$} & $\begin{array}{l}\text { Guru mengkondisikan } \\
\text { kembali } \\
\text { kelompok yang sudah } \\
\text { terbentuk } \\
\text { pertemuan sebelumnya }\end{array}$ & $\begin{array}{l}\text { Memperhatikan Instruksi } \\
\text { Guru dan Bergabung } \\
\text { dengan kelompoknya } \\
\text { masing-masing }\end{array}$ \\
\hline & $\begin{array}{l}\text { Menjelaskan materi luas } \\
\text { permukaan kubus dan } \\
\text { balok }\end{array}$ & $\begin{array}{l}\text { Menyimak dan } \\
\text { memperhatikan penjelasan } \\
\text { guru }\end{array}$ \\
\hline & $\begin{array}{l}\text { Memberikan contoh soal } \\
\text { terkait materi luas } \\
\text { permukaan kubus dan } \\
\text { balok dengan } \\
\text { mengaitkan materi } \\
\text { dengan benda-benda } \\
\text { dalam kehidupan sehari- } \\
\text { hari yang berbentuk } \\
\text { kubus dan balok }\end{array}$ & $\begin{array}{l}\text { Menyimak contoh yang } \\
\text { diberikan guru. }\end{array}$ \\
\hline & $\begin{array}{l}\text { Membagikan LKS pada } \\
\text { masing-masing } \\
\text { kelompok. }\end{array}$ & Mengerjakan LKS \\
\hline b. Elaborasi & $\begin{array}{l}\text { Memperhatikan, } \\
\text { memotivasi, } \\
\text { membimbing siswa pada }\end{array}$ & $\begin{array}{l}\text { Berdiskusi bersama teman } \\
\text { kelompoknya } \\
\text { Menganalisis }\end{array}$ \\
\hline
\end{tabular}




\begin{tabular}{|c|c|c|}
\hline & masing-masing & persmasalahan \\
\hline & kelompok & disajikan pada LKS \\
\hline & Mengakomodasi sumber & Memecahkan masalah yang \\
\hline & $\begin{array}{l}\text { belajar siswa yang } \\
\text { dibutuhkan }\end{array}$ & terdapat pada LKS \\
\hline & Membimbing & Menjawab pertanyaan guru \\
\hline & $\begin{array}{l}\text { dengan menggunakan } \\
\text { pertanyaan metakgonitif }\end{array}$ & \\
\hline \multirow[t]{9}{*}{ c. Konfirmasi } & Mengarahkan diskusi & Perwakilan masing-masing \\
\hline & kelompok & kelompok \\
\hline & & $\begin{array}{l}\text { mempersentasekan kerja } \\
\text { kelompoknya, }\end{array}$ \\
\hline & & Memperhatikan dan \\
\hline & & mengajukan pertanyaan \\
\hline & & $\begin{array}{l}\text { kepada kelompok lain yang } \\
\text { mempresentasikan hasil } \\
\text { diskusi kelompoknya }\end{array}$ \\
\hline & Memberikan & Memperhatikan penjelasan \\
\hline & balik positif & guru \\
\hline & penguatan & $\begin{array}{l}\text { Melengkapi, merevisi, dan } \\
\text { mengonstruksi hasil diskusi } \\
\text { kelompok }\end{array}$ \\
\hline \multirow{5}{*}{$\begin{array}{l}\text { Kegiatan } \\
\text { Penutup }\end{array}$} & \multirow[t]{2}{*}{ Menyimpulkan pelajaran } & Memperhatikan guru dan \\
\hline & & Menyimpulkan pelajaran \\
\hline & $\begin{array}{l}\text { Memberi pekerjaan } \\
\text { rumah }\end{array}$ & Mencatat pekerjaan rumah \\
\hline & $\begin{array}{l}\text { Menginformasikan } \\
\text { pembelajaran selanjutnya }\end{array}$ & $\begin{array}{l}\text { Menyimak informasi dari } \\
\text { guru. }\end{array}$ \\
\hline & $\begin{array}{r}\text { pelajaran } \\
\text { mengucapkan }\end{array}$ & Menjawab salam \\
\hline
\end{tabular}


c. Tahap Observasi

Tabel 6. Hasil Temuan Pada Proses Pembelajaran Siklus I dan Siklus II

\begin{tabular}{|c|c|c|}
\hline \multirow{2}{*}{$\begin{array}{c}\text { Tahap } \\
\text { Pembela- } \\
\text { jaran }\end{array}$} & \multicolumn{2}{|l|}{ Temuan } \\
\hline & Siklus I & Siklus II \\
\hline Apersepsi & 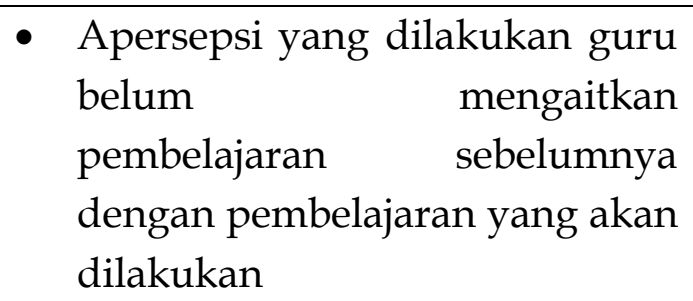 & \\
\hline Ekplorasi & $\begin{array}{l}\text { - Banyak siswa yang tidak } \\
\text { memperhatikan penjelasan guru } \\
\text { - Guru menyajikan contoh yang } \\
\text { minim sehingga banyak siswa } \\
\text { yang masih kurang mengerti } \\
\text { menyelesaikan soal yang } \\
\text { terdapat pada LKS }\end{array}$ & \\
\hline Elaborasi & $\begin{array}{l}\text { - Tidak semua siswa dalam } \\
\text { kelompok berpartisipasi aktif } \\
\text { dalam menyelesaikan kegiatan } \\
\text { pada LKS } \\
\text { - Siswa menyelesaikan kegiatan } \\
\text { pada LKS masih terpaku } \\
\text { dengan contoh yang diberikan } \\
\text { sehingga hasilnya kurang } \\
\text { mencerminkan kreativitas siswa }\end{array}$ & \\
\hline Konfirmasi & $\begin{array}{l}\text { - Banyak siswa yang tidak } \\
\text { memperhatikan siswa lain yang } \\
\text { maju presentasi } \\
\text { - Siswa pasif pada saat kegiatan } \\
\text { presentasi karena guru belum } \\
\text { memberikan kesempatan siswa } \\
\text { mengajukan pertanyaan } \\
\text { - Guru belum melakukan } \\
\text { konfirmasi terhadap materi } \\
\text { pembelajaran }\end{array}$ & $\begin{array}{l}\text { - Beberapa siswa } \\
\text { kurang } \\
\text { memperhatikan } \\
\text { siswa lain yang maju } \\
\text { presentasi } \\
\text { - Siswa yang aktif pada } \\
\text { saat presentasi masih } \\
\text { kurang namun sudah } \\
\text { meningkat dari siklus } \\
\text { sebelumnya. }\end{array}$ \\
\hline
\end{tabular}




\begin{tabular}{ll}
\hline Penutup $\quad$ Guru belum memotivasi siswa \\
\\
pentingnya mempelajari materi \\
selanjutnya
\end{tabular}

Tabel 7. Hasil Tes Siswa Kelas VIII B MTs Madani Alauddin Paopao

\begin{tabular}{cccc}
\hline & \multicolumn{3}{c}{ Siklus } \\
\cline { 2 - 4 } & Pre-Tes Pra-Siklus & Post-Test Siklus I & Post-Test Siklus II \\
\hline Rata-rata & 55,35 & 67 & 76,97 \\
\hline
\end{tabular}

Tabel 8. Keterampilan Pemecahan Masalah Matematika Siswa Kelas VIII B MTs Madani Alauddin Paopao

\begin{tabular}{|c|c|c|c|c|}
\hline \multirow{2}{*}{ Indikator } & \multirow{2}{*}{$\begin{array}{c}\text { Kategori } \\
\text { Keterampilan }\end{array}$} & \multicolumn{3}{|c|}{ Siswa } \\
\hline & & $\begin{array}{c}\text { Pre-Test Pra- } \\
\text { Siklus }\end{array}$ & $\begin{array}{c}\text { Post-Test } \\
\text { Siklus I }\end{array}$ & $\begin{array}{c}\text { Post-Test } \\
\text { Siklus II }\end{array}$ \\
\hline Memahami & Sangat Baik & 2 & 7 & 10 \\
\hline \multirow[t]{4}{*}{ Masalah } & Baik & 20 & 14 & 18 \\
\hline & Cukup Baik & 5 & 10 & 3 \\
\hline & Kurang Baik & 4 & 0 & 0 \\
\hline & Jumlah & 31 & 31 & 31 \\
\hline Menyusun & Sangat Baik & 0 & 8 & 9 \\
\hline \multirow[t]{4}{*}{ Rencana } & Baik & 14 & 19 & 21 \\
\hline & Cukup Baik & 16 & 4 & 1 \\
\hline & Kurang Baik & 1 & 0 & 0 \\
\hline & Jumlah & 31 & 31 & 31 \\
\hline Melaksanakan & Sangat Baik & 10 & 15 & 26 \\
\hline \multirow[t]{4}{*}{ Rencana } & Baik & 15 & 14 & 5 \\
\hline & Cukup Baik & 5 & 2 & 0 \\
\hline & Kurang Baik & 1 & 0 & 0 \\
\hline & Jumlah & 31 & 31 & 31 \\
\hline Memeriksa & Sangat Baik & 1 & 4 & 11 \\
\hline \multirow[t]{4}{*}{ kembali } & Baik & 11 & 16 & 18 \\
\hline & Cukup Baik & 16 & 11 & 2 \\
\hline & Kurang Baik & 3 & 0 & 0 \\
\hline & Jumlah & 31 & 31 & 31 \\
\hline
\end{tabular}


Tabel 9. Temuan dan Saran Siklus I dan Siklus II

\begin{tabular}{|c|c|c|}
\hline \multicolumn{2}{|c|}{ Siklus I } & \multirow[t]{2}{*}{ Siklus II } \\
\hline Temuan & Saran & \\
\hline $\begin{array}{lr}\text { Siswa } & \text { mengalami } \\
\text { kesulitan saat menjawab } \\
\text { apersepsi guru pada } \\
\text { sintaksa apesepsi. }\end{array}$ & $\begin{array}{l}\text { Guru melakukan apersepsi } \\
\text { dengan menvisualisasikan } \\
\text { dalam bentuk tanyangan } \\
\text { gambar, sehingga siswa } \\
\text { mudah memahami. }\end{array}$ & $\begin{array}{l}\text { Kesimpulan yang } \\
\text { dapat diperoleh } \\
\text { berdasarkan } \\
\text { tindakan siklus II } \\
\text { yaitu telah terjadi }\end{array}$ \\
\hline $\begin{array}{l}\text { Guru kurang menjelaskan } \\
\text { prosedur/tahapan } \\
\text { pembelajaran }\end{array}$ & $\begin{array}{l}\text { Guru disarankan } \\
\text { menjelaskan } \\
\text { prosedur/tahapan } \\
\text { pembelajaran }\end{array}$ & $\begin{array}{l}\text { peningkatan } \\
\text { keterampilan } \\
\text { pemecahan } \\
\text { masalah }\end{array}$ \\
\hline $\begin{array}{l}\text { Guru kurang } \\
\text { membimbing siswa dalam } \\
\text { merumuskan tujuan } \\
\text { pembelajaran }\end{array}$ & $\begin{array}{lr}\text { Guru } & \text { disarankan } \\
\text { membimbing } & \text { siswa dalam } \\
\text { merumuskan } & \text { tujuan } \\
\text { pembelajaran } & \end{array}$ & $\begin{array}{l}\text { matematika siswa } \\
\text { kelas VIII B MTs. } \\
\text { Madani Alauddin } \\
\text { Paopao. Hasil ini }\end{array}$ \\
\hline $\begin{array}{l}\text { Guru kurang memberikan } \\
\text { contoh dan soal pada LKS } \\
\text { terkait masalah dalam } \\
\text { kehidupan sehari-hari. }\end{array}$ & $\begin{array}{l}\text { Guru } \\
\text { memberikan contoh dan } \\
\text { soal pada LKS terkait } \\
\text { masalah dalam kehidupan } \\
\text { sehari-hari. }\end{array}$ & $\begin{array}{l}\text { menunjukkan } \\
\text { telah tercapainya } \\
\text { target penelitian. } \\
\text { Target penelitian } \\
\text { adalah } r \text { terjadi }\end{array}$ \\
\hline $\begin{array}{l}\text { Guru kurang } \\
\text { membimbing siswa dalam } \\
\text { merumuskan hipotesis }\end{array}$ & $\begin{array}{l}\text { Guru disarankan } \\
\text { membimbing siswa dalam } \\
\text { merumuskan hipotesis }\end{array}$ & $\begin{array}{l}\text { peningkatan } \\
\text { keterampilan } \\
\text { pemecahan }\end{array}$ \\
\hline $\begin{array}{l}\text { Guru kurang } \\
\text { membimbing siswa dalam } \\
\text { merencanakan percobaan }\end{array}$ & $\begin{array}{l}\text { Guru disarankan } \\
\text { membimbing siswa dalam } \\
\text { merencanakan percobaan }\end{array}$ & $\begin{array}{lr}\text { masalah } & \\
\text { matematika } & \text { siswa } \\
\text { pada } & \text { empat }\end{array}$ \\
\hline Ketika pembagian & Guru disarankan membagi & indikator \\
\hline $\begin{array}{l}\text { kelompok menyita banyak } \\
\text { waktu karena kelompok } \\
\text { dibagi secara langsung } \\
\text { saat pembelajaran, } \\
\text { sehingga alokasi waktu } \\
\text { tidak sesuai dengan RPP }\end{array}$ & $\begin{array}{l}\text { kelompok sebelum } \\
\text { pembelajaran, sehingga } \\
\text { siswa dapat langsung } \\
\text { menempatkan diri sesuai } \\
\text { dengan kelompoknya. }\end{array}$ & $\begin{array}{l}\text { keterampilan } \\
\text { pemecahan } \\
\text { masalah yaitu, } \\
\text { memahami } \\
\text { masalah, } \\
\text { menyusun }\end{array}$ \\
\hline $\begin{array}{ll}\text { Siswa tidak } & \text { mematuhi } \\
\text { pembagian } & \text { kelompok }\end{array}$ & $\begin{array}{l}\text { Guru lebih disiplin dan } \\
\text { memberi }\end{array}$ & $\begin{array}{l}\text { rencana, } \\
\text { melaksanakan }\end{array}$ \\
\hline
\end{tabular}




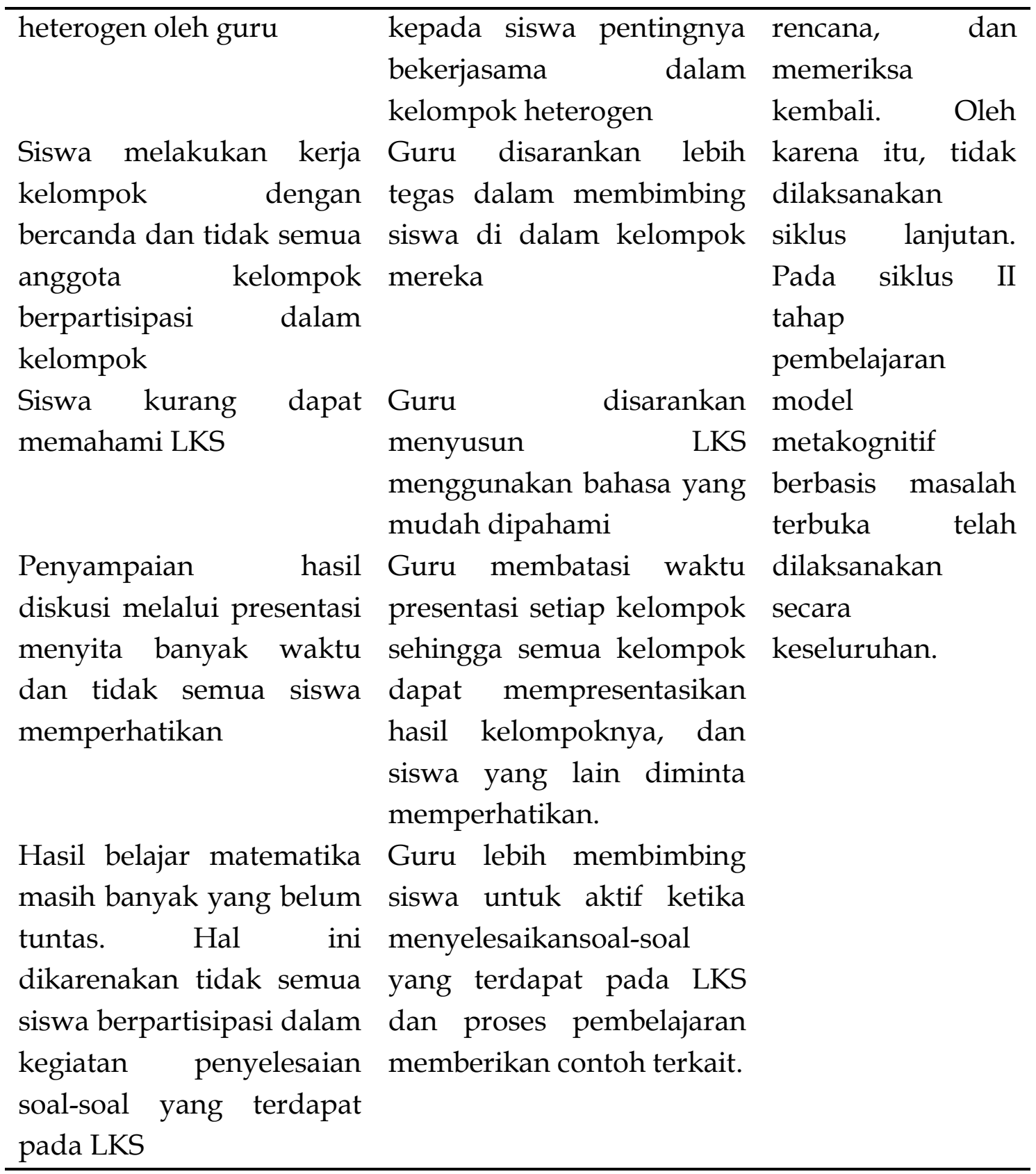




\section{Perbandingan Hasil Tindakan Antar Siklus}

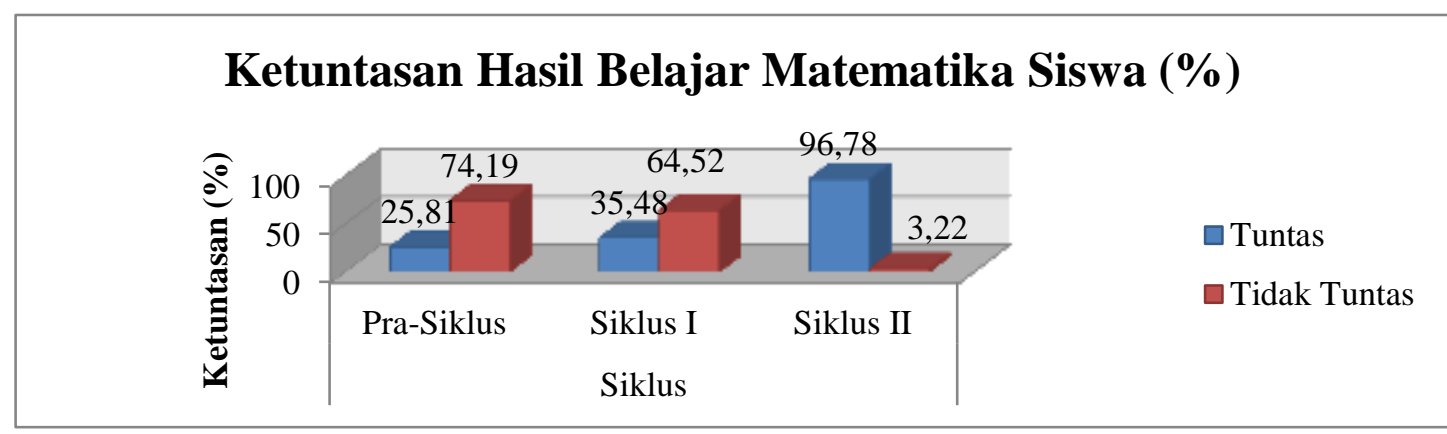

Gambar 1. Grafik Perbandingan Ketuntasan Hasil Belajar Matematika Siswa Pada Setiap Siklus

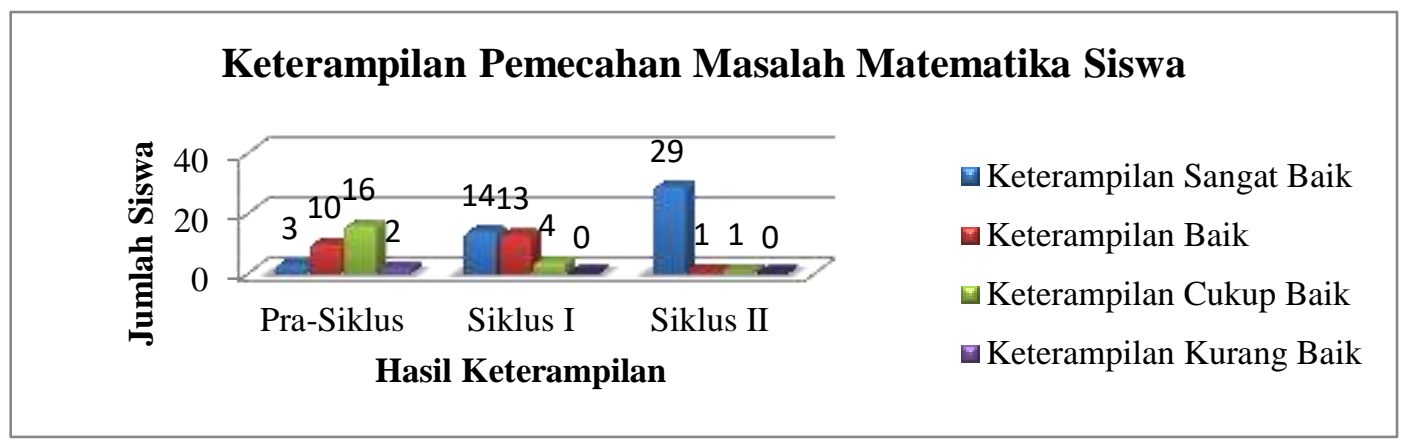

Gambar 2. Grafik Peningkatan Keterampilan Pemecahan Masalah Matematika Siswa Kelas VIII B MTs. Madani Alauddin Paopao

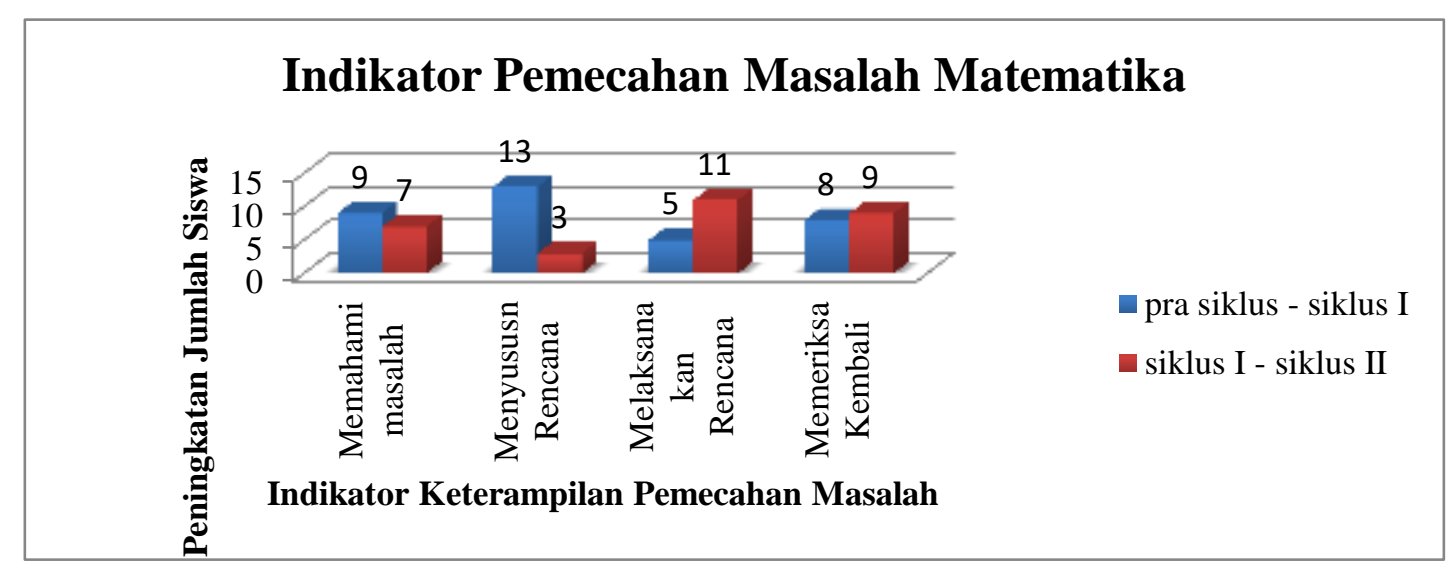

Gambar 3. Grafik Peningkatan Pemecahan Masalah Matematika Siswa Setiap Indikator Pemecahan Masalah

Secara umum, penerapan model pembelajaran metakognitif berbasis masalah terbuka ini menyebabkan skor kemampuan memecahkan masalah 
matematika siswa mengalami peningkatan dari sebelumnya. Adanya peningkatan ini dikarenakan oleh penerapan model pembelajaran yang lebih menekankan pada keaktifan siswa dalam kegiatan pembelajaran, sedangkan guru hanya berperan sebagai fasilitator. Dengan kata lain, pembelajaran berpusat pada siswa. Selain itu, model pembelajaran ini melatih siswa berpikir tingkat tinggi. Hal ini sejalan dengan pendapat Sudiarta (2010: 25-26) bahwa "kegiatan-kegiatan metakognitif berpotensi menghasilkan peserta didik yang memiliki kompetensi berpikir tingkat tinggi". Berpikir tingkat tinggi yang dimaksud adalah siswa mampu untuk merencanakan, memonitoring, dan merefleksi seluruh aktivitas kognitif sehingga apa yang dilakukan dapat terkontrol secara optimal. Sudiarta juga menyatakan bahwa metakognitif mencakup banyak hal, di antaranya mencakup masalah yang beragam dan mencakup tingkat pemikiran yang lebih besar tentang proses pembelajaran. Kemampuan siswa berpikir tingkat tinggi tersebut dapat membantu siswa dalam menyelesaikan suatu permasalahan matematika yang beragam tersebut. Untuk memfasilitasi siswa dalam kegiatan pembelajaran, maka digunakanlah soal atau masalah matematika terbuka.

\section{SIMPULAN}

Penerapan model pembelajaran metakognitif berbasis masalah terbuka dapat meningkatkan keterampilan pemecahan masalah matematika siswa. Peningkatan ini dikarenakan oleh penerapan model pembelajaran yang lebih menekankan pada aktivitas siswa dalam mengerahkan kesadaran dan pengaturan berpikirnya (metakognisi). Selain itu, dari empat indikator pemecahan masalah yang diukur, semuanya mengalami peningkatan dari siklus I ke siklus II.

\section{DAFTAR PUSTAKA}

Alimuddin. (2012). Proses berpikir kreatif mahasiswa calon guru kreatif dalam pemecahan masalah matematika berdasarkan gender. Disertasi. Tidak dipublikasikan. Surabaya: Program Pascasarjana Universitas Negeri Surabaya.

Anggo, M. (2011). Pelibatan metakognisi dalam pemecahan masalah matematika. Jurnal Edumatica 01 No. 01 (Edisi April 2011).

Arikunto, S. (2006). Dasar-dasar evaluasi pendidikan. Cet.VI; Jakarta: Bumi Aksara. 
Aqib, Z., dkk. (2009). Penelitian tindakan kelas untuk guru SD, SLB, dan TK. Cet.I; Bandung: Irama Widya.

Baker, L. (1989). Metacognition, comprehension monitoring and the adult reader. Educational Phychology Review, I, 3-38.

Baker, L., \& Brown, A. L. (1984). Metacognitive skills and reading. dalam p.d. pearson (ed.), handbook of reading research. New York: Longman.

Budhayanti, Clara I. S., dkk. (2008). Pemecahan masalah matematika. Jakarta: Dikti.

Kunandar. (2008). Langkah mudah penelitian tindakan kelas sebagai pengembangan profesi guru. Cet. I; Jakarta : Rajawali Press.

Lidinillah, D. A. M. (2008). Strategi pembelajaran pemecahan masalah di Sekolah Dasar, Jurnal Pendidikan Dasar, no. 10 (Oktober 2008).

Myers, M. I. I., \& Paris, S.G. (1978). Children's metacognitive knowledge about reading. Journal of Educational Psychology, 70.

Schoenfeld, H. A. (1994). Mathematical thinking and problem solving. New Jersey: Lawrence Erlbaum Assosiates Publishers.

Sulasteri, S. (2012). Penelitian tindakan kelas teori dan aplikasi. Cet I; Makassar: Alauddin University Press.

Syaiful. (2012). Peningkatan kemampuan pemecahan masalah matematis melalui pendekatan pendidikan matematika realistik. Jurnal Edumatica 02 No. 1, April 2012. 